\title{
Efek Ekstrak Buah Kersen (Muntingia Calabura) terhadap Jumlah Sel Epitel Bersilia Bronkus pada Tikus Wistar yang Dipapar Asap Rokok.
}

The Effects of Kersen Fruit Extract (Muntingia Calabura) on the Number of Bronchial Ciliated Epithellium Cells on Cigarette Smoke Exposed Wistar Rats

\author{
Afiana Rohmani ${ }^{1)}$, Ika Dyah Kurniati 1) \\ 1)Bagian Biomedik, Fakultas Kedokteran, Universitas Muhammadiyah Semarang \\ Fakultas Kedokteran Universitas Muhammadiyah Semarang. \\ Jl. Wonodri Sendang Raya 2A, Semarang. Email: afi.darwis@yahoo.com
}

\begin{abstract}
Abstrak
Latar Belakang : Asap rokok menyebabkan stress oksidatif dan memicu aktifitas Epidermal Growth Factor Receptor (EFGR) pada sel epitel bronkial, sehingga menyebabkan hiperplasia dan peningkatan jumlah sel epitel tersebut. Buah kersen (Muntingia Calabura) mempunyai aktifitas antioksidan yang kuat dan diharapkan dapat menurunkan jumlah oksidan yang ditimbulkan oleh paparan asap rokok. Tujuan penelitian ini adalah mengetahui efek ekstrak buah kersen terhadap jumlah sel epitel bersilia pada saluran nafas pada tikus wistar yang dipapar asap rokok.

Metode : Tikus wistar berjumlah 24 ekor dibagi menjadi 4 kelompok : kelompok kontrol negatif (K-) diberikan plasebo saja, kelompok kontrol positif $(\mathrm{K}+)$ diberikan plasebo dan dipaparkan asap rokok, kelompok perlakuan 1 (P1) dan kelompok perlakuan 2 (P2) yang dipapar asap rokok dan diberi ekstrak buah kersen per oral dengan dosis $100 \mathrm{mg} / \mathrm{kg} \mathrm{BB} /$ hari dan $200 \mathrm{mg} / \mathrm{kgBB} /$ hari. Pemaparan asap rokok dilakukan selama 30 menit setiap hari. Perlakuan ini dilakukan selama 20 hari , kemudian semua binatang coba diterminasi. Kemudian dilakukan analilsis sel epitel bronkial.

Hasil : Melalui analisis Kruskal Wallis menunjukkan perbedaan yang signifikan $(\mathrm{p}=0,000)$ antara jumlah sel sepitel bersilia pada kelompok kontrol negatif (K-) dengan kelompok kontrol positif $(\mathrm{K}+)$. Terdapat perbedaan yang signifikan $(\mathrm{p}=0,001)$ jumlah epitel bersilia antara kelompok kontrol positif $(\mathrm{K}+)$ dengan kelompok perlakuan 1 (P1).
\end{abstract}

Simpulan : Pemberian ekstrak buah kersen dengan dosis $100 \mathrm{mg} / \mathrm{kgBB} /$ hari memberikan efek signifikan dalam hal menurunkan jumlah sel epitel bersilia bronkial pada tikus yang dipapar asap rokok.

Kata kunci : asap rokok, buah kersen, sel epitel bersilia. 


\section{Abstract}

Background: Cigarette smoke causes oxidative stress and triggers the activity of Epidermal Growth Factor Receptor (EFGR) in epithellium bronchial cells that lead to hyperplasia and increasing the number of cells. Kersen fruit (Muntingia calabura Linn) has strong antioxidant activity, was expected to decrease the amount of oxidant caused by cigarette smoke exposure. The purpose of this study was to examine the effect of kersen fruit extract on the number of ciliated bronchial epithellium cells in wistar rats exposed to cigarette smoke.

Methods: 24 rats were divided into 4 groups : Negative control group (C-) received a placebo, while the positive control group $(\mathrm{C}+)$ received a placebo and cigarrete smoke. Both treatment groups 1 (T1) and groups 2 (T2) exposed cigarrete smoke and received kersen extract by gavage at a dose of 100 $\mathrm{mg} / \mathrm{kgBW} /$ day and $200 \mathrm{mg} / \mathrm{kgBW} /$ day. The cigarrete smoke were exposed for 30 minutes in each day. These intervention were carried out for 20 days, and finally the animals were terminated. The differences in bronchial epithellium cells were then analyzed.

Results: The Kruskal Wallis analysis showed significant differences $(p=0,000)$ in the ammount of ciliated epithelium cells in negative control group (C-) compare with positive control group $(\mathrm{C}+)$. There were significant difference $(p=0.001)$ in the ammount of ciliated epithellium cells in positive control group $(\mathrm{C}+)$ compare with treatment group 1 (T1).

Conclusion: Receiving kersen fruit extract $100 \mathrm{mg} / \mathrm{kgBW}$ has significant effect on reducing the ammount of ciliated bronchial epithellium cells in rats exposed to cigarettes.

Keywords: cigarette smoke, kersen fruit, ciliated epithellium cells

\section{INTRODUCTION}

Smoking produces a shift in the normal balance between oxidants and antioxidants to impact an oxidative stress in the bronchial, lungs and systemically. Oxidants in cigarrete smoke can directly injure cells and tissue, inactive defence mechanisms, and initiate inflammation, which is further elevates oxidative stress. There cigarette smoke induced chronic obstructive pulmonary disease (COPD), a common chronic respiratory disease, is the third leading cause of death in the world, after ischemic heart desease and cerebrovascular disease. (1,2,3)

According to WHO, Indonesia has the most active smoker number 3 in the world, after China and India, which amounted to 61.4 million. The data also states that smoking behavior of Indonesian people is increasing from $34.2 \%$ in 2007 to $36.3 \%$ in $2003 \cdot(3)$
Oxidative stress due to smoke-free radicals triggers the activity of Epidermal Growth Factor Receptor (EGFR) in epithellium bronchial cells, resulting in hyperplasia and increasing the number of epithellium cells. Hyperplasia of mucous cells and superficial airway epithellium are associated with the mechanism of COPD. $1,4,5)$

Reported by WHO, there is an increasing demand and use of herbal medicines around the world. In comparison with conventional drugs and synthetic vitamin, herbal medicines are sought for their widespread availability and have been reported to be well tolerated by patients with lower incidences of side effects compared with converntional drugs. Herb from plant mostly are contain natural antioxidant phenolic compounds. Antioxidants are chemical compounds that may donate one or 
more electrons to free radicals, therefore it inhibited free-radical reactions. ${ }^{(6,7)}$

One of the plants that has potential as a source of natural antioxidants is kersen (Muntinga Calabura). Kersen fruit known as Cherry, a member of family Elaeocarpaceae, native from Southern Mexico, the Caribbean, Central America and South America to the west. This plant can quickly spread to Asian mainland through the bird, so kersen also wellknown as hummingbirds. In Indonesia this plant is particularly usefull as a shade tree by the road side. In Indonesia the utilization of kersen fruit is not optimum, considering there is minimum economic value and the lack of knowledge about kersen fruit's utilization. The extraction of several studies show quantitative results that kersen has antioxidants activitities because of it contain of highly ascorbit acid (33,6 mg AAE/g ekstrak), vitamin $\mathrm{E}(14,7 \mathrm{mg} \mathrm{TE} / \mathrm{g}$ ekstrak), total fenol (121,1 mg GAE/g ekstrak), flavonoid (173,2 mg RE/g ekstrak) dan antosianin (82,4 mg CGE/g ekstrak. Flavonoids wellknown has a high antioxidant activity consist of falvonol, flavanon, flavones, isoflavones, catechin and kalkon. $(8,9,10,11)$

Based on the description above there are some questions and need further investigation whether kersen those have antioxidant activity are able to eliminate oxidative stress damage resulting from cigarette smoke exposure? In this study, rats were exposed to cigarette smoke, and kersen fruit were then administration. The kersen fruits were made of pure dry extract without taking certain elements because it is cheaper and easy to apply in society and daily life. Cherries that have antioxidant effect were expected to repair bronchial epithellium and ciliated damage caused by oxidative stress of cigarette smoke. The oxidative stress damage were assessed by counting the number of bronchial epithellium ciliated cells on histopathologic examination, also comparing the differences between the treatment groups given kersen extract and the placebo control group. The purpose of the study was to examine the difference number of ciliated epithellium bronchial of exposed cigarette smoke - rat with and without giving kersen fruit extract.

\section{METHODS}

\section{Design of the study}

This was an experimental laboratory study of post test control group design using Wistar rats as experimental subjects. The study was carried out in October 2016 for a period of 4 weeks. The study setting was at the Inter University Center (Pusat Antar Universitas) of Gajah Mada University (PAU UGM), Yogyakarta, and the Pathologic Anatomy laboratory of Diponegoro University (UNDIP), Semarang.

\section{Animals.}

The male Wistar rats used in this study were obtained from Gajah Mada University, Yogyakarta, according to the following inclusion criteria: weight 150 - 200 grams, age 12 weeks, in healthy and active condition, and with normal external anatomic features. Exclusion criteria: rats dying or becoming ill during the study. The minimum number of animals required for each group was 5, thus for 3 groups 15 animals were 
needed. In anticipation of dropouts one animal was added to each group. The sample size were according to the Research Guidelines for Evaluation the Safety Efficiency of Herbal Medicines in World Health Organization (WHO). Thus, in this study there were 6 animals in each group.

\section{Preparation of kersen fruit extract}

Kersen fruit was taken from kersen tree at Sleman district kersen (Muntingia calabura). Fruit with half ripe condition were selected because of the low alkaloid contents. The fruits were cleansed, cut up into small parts, and left to dry thoroughly in the sun. The fruits also dried by incubator at $37^{\circ} \mathrm{C}$ for $6 \times 24$ hours until the water contain in the fruit were remove and certainly dry. Dried fruits were powdered with pounding. The powder was extracted with a maceration method, which was mixed with $70 \%$ ethanol and shaken with mixer in order to reach a homogenous solution. After 48 hours the solution were filtered with a paper filter Buchner funnel. This was done for 30 minutes in order to separate the filtrate and the residu. The last step was to macerate the filtrate resulting the thick dense extract and the concentration reached $99 \%$. The doses of the extract fruit made in this study were $100 \mathrm{mg} / \mathrm{kg} \mathrm{BW}$ and 200 $\mathrm{mg} / \mathrm{kg}$ BB. Kersen fruit extract were given 30 minutes after expossing cigarrete smoke every day for 20 days.

\section{Intervention.}

The rats were adapted to feed for 1 week, kept in a room at a temperature of $25 \pm 2{ }^{\circ} \mathrm{C}$ and 65 $70 \%$ humidity, with a 12-hour light and dark cycle. Animals were then randomly assigned to four groups : negative control group (C-) received a placebo, while the positive control group $(\mathrm{C}+)$ reeceived a placebo and cigarrete smoke. Both treatment groups 1 (T1) and groups 2 (T2) exposed cigarrete smoke and received kersen extract by gavage at a dose of $100 \mathrm{mg} / \mathrm{kgBW} / \mathrm{day}$ and $200 \mathrm{mg} / \mathrm{kgBW} /$ day. The intervention was done for 20 days. The cigarrete smoke were exposed for 30 minutes in each day.

\section{Histological analysis .}

For the histological analysis, rats were sacrificed by cervical dislocation under anesthesia after 20 days intervention. The extracted bronchus were fixed in $10 \%$ buffered formalin, at a ratio of 1 part bronchus tissue and 9 parts $10 \%$ buffered formalin, and further fixed for at least 24 hours. Tranversal section were cut from parafinembedded tissues, placed on poly-lysin-coated slides, and the incubated overnight at $55-60^{\circ} \mathrm{C}$. Deparaffinized sections were stained with hematoxylin and eosin ( $\mathrm{H} \& \mathrm{E})$. After that, pathological conditions in the bronchus tissues were visualized under a light microscope. The epithellium cells of bronchus were examined histologically for structural changes, followed by counting ciliated epithelium cells which done by double blind using counter. The persentage of cilia epithellium cells were comparison between amount of ciliated epithellium cells and the total amount of all bronchial epithellium cells including goblet cells. The evaluation and cell count results were compared with those of our pathologist, and in case of differing results, a consensus was reached. 


\section{Statistical analysis .}

The statistical analysis was done by using the SPSS computer program. The data were evaluated for normality by means of the Kolmogorof Smirnof test. The scientific statistical significance for between-group differences was done by Kruskall Wallis, followed inter group comparison by Mann Whitney . The level of significance was set at 0.05 .

\section{Ethical clearance.}

This study was carried out after obtaining ethical clearance from the Commision for Medical Research Ethics, Faculty of Medicine, Diponegoro University, Semarang.

\section{RESULTS AND DISCUSSION}

There were two rats from positive control group $(\mathrm{C}+)$ (smoke control group) died during the first week, and another two rats died during the third week. Therefore, there were two rats left in this group $(\mathrm{C}+)$ until termination time. In order to complete the data, the calculation of bronchial epithellium cells was performed on both remaining samples in different fields of view.

The evaluation and cell count results were compared with those of our pathologist, within five different fields of view in each histologycal preparation.

Table 1. Discriptive analysis of the ammount of cilia epithel cells of trachea in each group

\begin{tabular}{llllll}
\hline Group & Mean & Median & Std. Deviation & Minimum & Maxsimum \\
\hline $\mathrm{C}(-)$ & 90,88 & 91,00 & 6,160 & 80 & 101 \\
\hline $\mathrm{C}(+)$ & 61,88 & 60,00 & 10,450 & 50 & 83 \\
\hline T1 & 80,88 & 85,00 & 12,879 & 55 & 99 \\
\hline T2 & 68,28 & 66,00 & 12,857 & 52 & 90 \\
\hline
\end{tabular}
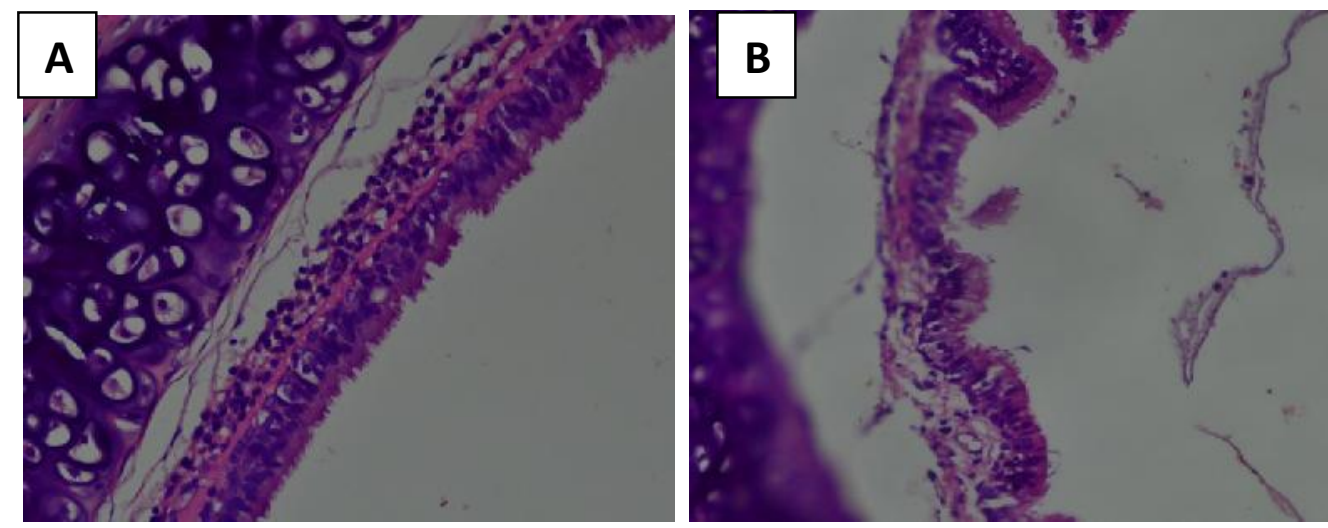

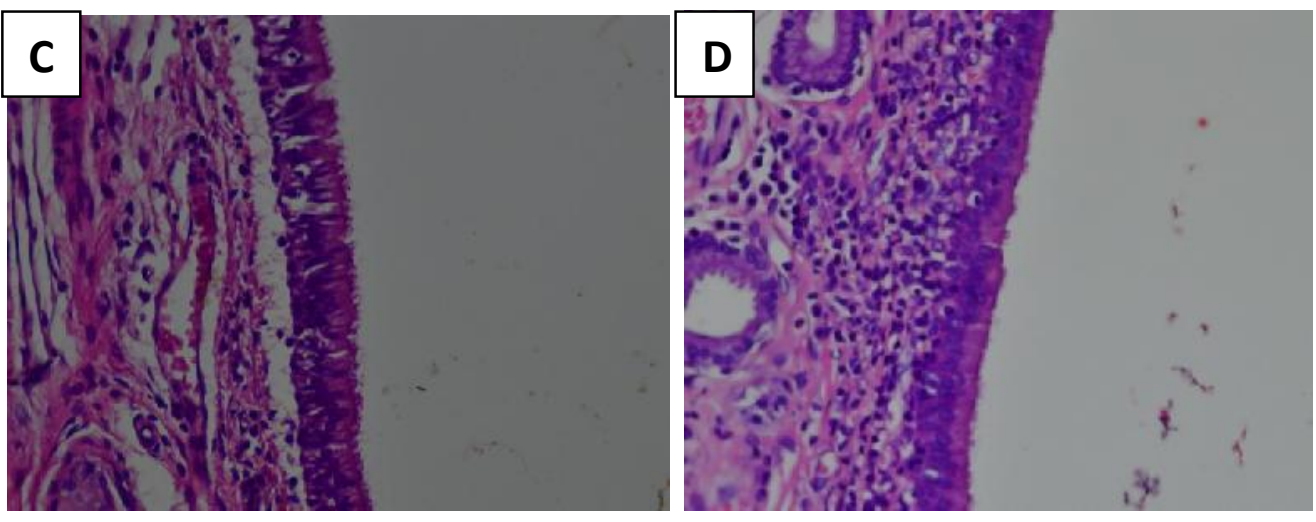

Fig.1. Histopathological appearence in each groups.

There were significant differences in mean numbers of bronchial ciliated epithellium cells between four groups. The negatif control (C-) receiving only placebo, showed the highest mean number of cilia epithel cells at 90,88 $\pm 6,160$ compared with the positive control group $(\mathrm{C}+)$
$(61,88 \pm 60,00)$, the treatment group receiving a dose of $200 \mathrm{mg} / \mathrm{kgBW} /$ day kersen extract $(80,88$ $\pm 85,00)$ and a dose of $100 \mathrm{mg} / \mathrm{kgBW} /$ day kersen extract $(68,28 \pm 66,00) \quad(p=0.000)$. The differences in results after Mann Whitney analysis are presented in Table 2 .

Table 2. Differences in mean number of ciliated epithellium cells between groups.

\begin{tabular}{|c|c|c|c|c|c|}
\hline & $C(-)$ & $\mathrm{C}(+)$ & T 1 & T 2 & $\mathrm{P}$ \\
\hline$C(-)$ & - & $0,000^{*}$ & $0.001 *$ & $0.000^{*}$ & 0,000 \\
\hline $\mathrm{C}(+)$ & $0,000^{*}$ & - & $0,000^{*}$ & 0,102 & \\
\hline T1 & $0.001 *$ & $0,000^{*}$ & - & $0,001 *$ & \\
\hline $\mathrm{T} 2$ & $0.000^{*}$ & 0,102 & $0,001^{*}$ & - & \\
\hline
\end{tabular}

The negatif control (C-) receiving only placebo, showed the highest mean number of ciliated epithellium cells at 90,88 \pm 6,160. Compared by Mann Whitney analysis with the whole three other groups, the negative control groups (C-) has significantly difference. The cigarette smoke exposure were reliable too strong, this was proven by the death of four rats in this group. Cigarette smoke resulting free radicals causing oxidative stress at the exposured tissue. In bronchial epithellium, radical free exposure causes hyperplasia as a consequence of the inflammatory process, associated with protective mechanism to treat external pathogens. Hyperplasia and the increase of epithellium cells due to oxidative stress was caused by the activity of Epidermal Growth Factor Receptor (EFGR). These receptors were involved in the process of cell proliferation and deformation, therefore EFGR activation will stimulate the differentiation of ciliated epithelial cells into goblet cells/ mucous produce -cells. (4) Simulated stress cells will have cellular adaptation responses both physiologically and morphologically. Adaptation response would formed hypertrophy, hyperplasia, and 
differentiation. (11) According the number of ciliated epithellium cells in the positive control group ( smoke control group) which is less then the negative control group (placebo group), possibly due to the differentiation of epithellium cells into goblet cells (mucous produce-cells) and also the cell death process.

There were significant differences $(p=0,00)$ between the positive control group $(\mathrm{C}+)$ (smoke control group) and the treatment group 1 (T1) ( kersen fruit extract $100 \mathrm{mg} / \mathrm{kgBW})$. The number of ciliated epithellium cells at kersen extract treatment group had more number than the positive control group $(\mathrm{C}+)$ (smoke control group). This reimprove the presence of antioxidant contained in kersen that are able to prevent free radicals due to cigarette smoke, thus the number of ciliated epithellium cells were likely more, not experiencing death nor damage.

However, there were no significant differences between the positive control group (smoke control group) and the tratment group 2 (kersen fruit extract $200 \mathrm{mg} / \mathrm{kgBW}$ ), meaning that kersen extract at the dose of $200 \mathrm{mg} / \mathrm{kgBW}$ had no appreciable effect on cellular recovery from cigarrete smoke lesions. This was remaining need to be more observe.

\section{CONCLUSSION}

Receiving kersen fruit extract 100mg / $\mathrm{kgBW}$ has significant effect on increasing the ammount of ciliated epithellium cells in rats exposed to cigarettes.

\section{REFERENCES}

1 Rabe Klaus F, Watz Henrik. Chronic Obstuction Pulmonary desease. The Lancet. 2017. Vol 389, issue 10082: 1931-40

2 Chuanhua Ma, Hongyan Long, Betulin inhibated cigarette smoke-induced COPD in mice. Journal Biomedicine and Pharmacotherapy. 2017; 85 : 679-86

3 World Health Organization. Global Alliance against Chronic Respiratory Diseases (GARD). General Meeting Report; 2008 May 30-31; istanbul, Turkey. Geneva: WHO; 2008

4 Mudjiwijono Handaru E1, Nunuk Sri M2, Indah Srini Nk3 Pemberian Jus Tomat (Lycopersicum esculentum) Per Oral Dapat Menurunkan Jumlah Sel Epitel Bronkhus Utama Tikus Putih yang Dipapar Asap Rokok Sub Kronik. Jurnal Kedokteran Brawijaya, Vol. 26, No. 1, Februari 2010. 3226

5 Stephan F. van Eeden, Adam Yeung, Kevin Quinlam, and James C. Hogg. Systemic Response to Ambient Particulate Matter Relevance to Chronic Obstructive Pulmonary Disease. Proc Am Thorac Soc Vol 2. pp 61-67, 2005

6 Lin JT, Chen YC, Chang YZ, Effective compounds in the fruit of Muntingia calabura Linn. cultivated in Taiwan evaluated with scavenging free radicals and suppressing LDL oxidation. Food and Function. 2017.8 issue 4 : 1504-11

7 Wong ZW, Thanikachalam PV, Ramamurthy S. Molecular understanding of protective role of natural products on isoproterenol-induced myocardial infarction. Biomedicine and Pharmacotherapy. 2017. Vol 94 : 1145-66

8 Nivethetha M., Jayasri J., and Brindha P.: Effects of Muntingia calabura L. on isoproterenol-induced myocardial infarction. Singapore Med. J. 2009; 50: pp. 300-302

9 Triswaningsih D, Kumalaningsih S. Identification of Cehmical compounds cherry leaves (Muntinga Calabura) powder 
as a natural antioxidant. 2017. IJAAR. Vol $10.5: 84-91$.

10 Gomathi R, Anusuya N and Manian S. A Dietary Antioxidant Supplementation of Jamaican Cherries (Muntingia Calabura L) Attenuates Inflammatory Related Disorders. Food Sci.Biotechnol. (2013);22(3): 787-794
11 Triwaningsih, Kumalaningsih. Estimation of chemical compouds and antioxidant activity of Muntinga Calabura extract. IJCRGG. Vol 10, $3: 17-23$.

12. Kumar Vinnay, Abbas, Cell injury, Cell death and adaptation. In: Robbins Basic Pathology. 10th ed. Elsevier. 2018. P.31-56 